\title{
MANAJEMAN ZAKAT PADA BADAN AMIL ZAKAT NASIONAL KOTA MAKASSAR
}

\author{
Trisno Wardy Putra \\ Fakultas Ekonomi dan Bisnis Islam Universitas Islam Negeri Alauddin Makassar, Email : \\ wardy.mujahid@gmail.com
}

\begin{abstract}
ABSTRAK
Pengelolaan zakat harus dibangun atas nilai-nilai Islami, baik itu dari tataran perencanaan, pengorganisasian, pelaksanaan (penghimpunan\&pendistribusian), maupun pengawasan. Penelitian ini bertujuan untuk menganalisis manajemen zakat pada BAZNAS Kota Makassar. Metode yang digunakan dalam penelitian ini adalah metode kualitatif dan analisis data yang digunakan adalah deskriptif analistik. Hasil penelitian ini menunjukkan bahwa manajemen zakat Badan Amil Zakat Nasional Kota Makassar sudah baik namun perlu dicarikan solusi kongkrit dari kendala-kendala yang dihadapi.
\end{abstract}

Kata-kata kunci : Manajemen, Zakat, Amil

\section{ABSTRACT}

Zakat management must be built on Islamic values, both from the level of planning, organizing, implementing (collecting and distributing), as well as supervision. This study aims to analyze the management of zakat at the BAZNAS Makassar City. The method used in this study is a qualitative method and data analysis used is descriptive analytic. The results of this study indicate that the zakat management of the Makassar City Amil Zakat Agency is already good but it needs to find a concrete solution of the obstacles encountered.

Keywords : Management, Zakat, Amil

\section{PENDAHULUAN}

Pasca pemberlakuan Undang-Undang RI Nomor 38 tahun 1999 tentang Pengelolaan Zakat. Eksistensi institusi zakat, baik yang dibentuk oleh pemerintah lahir dari inisiatif masyarakat yang kian penting dan strategis. (Irfan, et.all, 2011: 1). Dalam Undang-Undang RI Nomor 38 tahun 1999 tentang Pengelolaan Zakat Bab III pasal 6 dan pasal 7 menyatakan bahwa lembaga pengelola zakat di Indonesia terdiri dari dua macam, yaitu: Badan Amil Zakat (BAZ) dan Lembaga Amil Zakat (Laz). (Didin, 2002: 130). Pembentukan institusi zakat tersebut bertujuan untuk membantu pemerintah dalam pengentasan kemiskinan di Indonesia.

UU No.38 Tahun 1999 Tentang Pengelolaan Zakat sudah direvisi dengan UU No. 23 tahun 2011 Tentang Pengelolaan Zakat. Setelah 
disahkannya UU Pengelolaan Zakat tersebut Indonesia telah memasuki tahap institusionalisasi pengelolaan zakat dalam wilayah formal kenegaraan, meskipun masih sangat terbatas. Lembaga-lembaga pengelola zakat mulai berkembang, termasuk pendirian lembaga zakat yang dikelola oleh pemerintah, yaitu BAZNAS (Badan Amil Zakat Nasional), BAZDA (Badan Amil Zakat Daerah) dan LAZ (Lembaga Amil Zakat) yang dikelola masyarakat dengan manajemen yang lebih baik dan modern.

Setidaknya dengan UU Zakat tersebut telah mendorong upaya pembentukan organisasi pengelola zakat yang amanah, kuat dan dipercaya masyarakat. Tentu saja hal ini meningkatkan pengelolaan zakat sehingga peran zakat menjadi lebih optimal. Organisasi pengelola zakat telah mampu mengelola dana hingga puluhan milyar rupiah, dengan cakupan penyalurannya mencapai seluruh wilayah Indonesia. Menurut hasil riset Badan Amil Zakat Nasional (BAZNAS), FEM IPB dan IDB, terjadi kenaikan potensi zakat di Indonesia sebesar Rp.217 trilyun atau 3,14\% dari GDP (Gross Domestic Product) Indonesia. Namun di dalam UU perzakatan di Indonesia belum ada sanksi yang tegas bagi masyarakat yang tidak mengeluarkan zakat, sehingga potensi zakat belum dihimpun secara maksimal. Untuk potensi zakat di Kota Makassar sangat besar, diperkirakan mencapai Rp 7 miliar per tahun, namun yang baru terserap sekitar Rp. 1 miliar kata Wali Kota Makassar Ilham Arief Sirajuddin pada dialog pemberdayaan zakat untuk memberantas kemiskinan di Pesantren Hidayatullah Makassar. Bahkan beliau juga mengatakan bahwa sekitar 80 persen dari 1,3 juta warga Makassar adalah muslim, yang memiliki kewajiban membayar zakat bagi yang mampu. Oleh karena itu, untuk mengoptimalkan peran dari Badan Amil Zakat Nasional Kota Makassar perlu dilakukan penelitian untuk menganalisa manajemen zakat yang telah dilakukan.

\section{METODE PENELITIAN}

Pada penelitian ini digunakan pendekatan kualitatif. Dimana penulis menggunakan wawancara, observasi langsung ke lapangan, dan analisis dari bahan-bahan tertulis sebagai sumber data utama. Menurut Nawawi, penelitian kualitatif sebagai suatu konsep keseluruhan (holistik) untuk mengungkapkan sesuatu dilakukan dengan menghimpun data dalam keadaan sewajarnya (natural setting) mempergunakan cara kerja yang sistematik, terarah dan dapat di pertanggung jawabkan secara kualitatif, 
sehingga tidak kehilangan sifat ilmiahnya. (Hadari dan Hilmi, 1996: 175). Tipe kajian dalam penelitian ini adalah bersifat deskriptif, karena bermaksud menggambarkan secara jelas dan rinci fenomena yang menjadi pokok permasalahan tanpa melakukan hipotesis atau perhitungan secara statistik.

Sumber data dalam penelitian ini adalah kata-kata dan tindakan para informan sebagai data primer dan tulisan atau dokumen-dokumen yang mendukung pernyataan informan. Penelitian ini membutuhkan sumber data primer dan data sekunder. Data primer adalah data yang diperoleh dari penelitian lapangan. Data primer ini akan diperoleh melalui informan yang memenuhi kriteria sebagai berikut: pertama, pihak yang memahami dan menguasai permasalahan pengelolaan zakat dan hukum zakat, kedua, pihak yang sedang terlibat langsung dalam kegiatan pengelolaan zakat, khususnya Badan Amil Zakat Daerah Kota Makassar. Data sekunder adalah data yang berasal dari bahan kepustakaan guna memperoleh suatu landasan teoritis berupa pendapat atau tulisan-tulisan para ahli hukum, peraturan perundang-undangan yang tertulis (hukum positif di Indonesia), sumber hukum Islam khususnya yang berhubungan dengan pokok permasalahan tersebut, serta dokumen-dokumen, arsip dan data yang lainnya yang diperlukan.

Teknik pemilihan informan yang digunakan dalam penelitian ini adalah purposive sampling yaitu informan yang dipilih dengan secara sengaja atau menunjuk langsung kepada orang yang dianggap dapat mewakili karakteristik-karakteristik populasi. Data yang diperlukan dalam penelitian ini akan dikumpulkan melalui tiga cara yaitu: observasi, wawancara (interview), dan studi kepustakaan (library research). Adapun tahapan-tahapan yang dilakukan pada penelitian ini adalah sebagai berikut: pertama, pada tahap observasi, cara ini dilakukan untuk memperoleh gambaran yang bersifat umum dan relatif menyeluruh, tentang apa yang tercakup di dalam fokus permasalahan yang akan diteliti. Kedua, wawancara, baik dengan cara terstruktur maupun tidak terstruktur, yaitu wawancara yang dilakukan baik dengan menetapkan sendiri masalah dan pertanyaan-pernyataan yang akan diajukan maupun pertanyaan yang berkembang dalam waktu wawancara terjadi untuk memberi jawaban terhadap pokok permasalahan. Ketiga, studi kepustakaan (library research) yaitu meneliti berbagai literatur sebagai dokumen serta bahan-bahan yang 
berkaitan dengan permasalahan penelitian.

Teknik analisis data yang digunakan dalam penelitian ini adalah sebagaimana yang dikemukakan Moleong. (Moleong, 2007: 249), proses analisis data kualitatif adalah sebagai berikut: pertama, menelaah seluruh data yang tersedia dari berbagai sumber, yaitu dari wawancara, pengamatan yang sudah dituliskan dalam catatan lapangan, dokumen pribadi, dokumen resmi, gambar, foto, dan lain sebagainya. Kedua, mengadakan reduksi data yang dilakukan dengan jalan abstraksi. Abtraksi merupakan usaha membuat rangkuman yang inti, proses dan pernyataan yang perlu dijaga, sehingga tetap berada di dalamnya. Ketiga, menyusunnya ke dalam satu-satuan itu, kemudian dikategorisasikan pada langkah berikutnya. Keempat, mengadakan pemeriksaan keabsahan data.

\section{HASIL DAN PEMBAHASAN}

1. Pengetian, Hukum, Hikmah, dan Jenis Zakat

Zakat berasal dari bentukan kata zaka yang berarti 'suci', 'baik', 'berkah', 'tumbuh', dan 'berkembang'. Senada dengan Yusuf Qardhawi bahwa kata dasar zaka berarti bertambah dan tumbuh, sehingga bisa dikatakan bahwa "tanaman itu $z a k a$ ", artinya tanaman itu tumbuh. (Muhammad, 2007: 153) Menurut terminologi syariat (istilah), zakat adalah nama bagi sejumlah harta tertentu yang diwajibkan oleh Allah untuk dikeluarkan zakat dan diberikan kepada yang berhak menerimanya dengan persyaratan tertentu pula. Kaitan antara makna secara bahasa dan istilah ini berkaitan erat sekali, yaitu bahwa setiap harta yang sudah dikeluarkan zakatnya akan menjadi suci, bersih, baik, berkah tumbuh, dan berkembang (at-Taubah: 103 dan Ar-Rum: 39). (Didin, 1998: 13).

Zakat dalam istilah fiqih berarti sejumlah harta tertentu yang diwajibkan Allah SWT diserahkan kepada orang-orang yang berhak. (Qardawi, 1999: 34). Pengertian secara syara' zakat mempunyai banyak arti, diantaranya: (Amiruddin, et.all, 2000:9-10). Menurut Yusuf Qardhawi, zakat adalah sejumlah harta tertentu yang diwajibkan oleh Allah SWT dan diserahkan pada orang-orang yang berhak. Abdur Rahman al-Jazari berpendapat bahwa zakat adalah penyerahan kepemilikan kepada orang yang berhak menerimanya dengan syarat-syarat tertentu pula. Muhammad al-Jurjani, mendefinisikan zakat sebagai kewajiban yang telah ditentukan oleh Allah SWT bagi orang-orang Islam untuk mengeluarkan sejumlah 
harta yang dimiliki. Dari pengertian-pengertian tersebut dapat dipahami bahwa zakat adalah ibadah dalam Islam dan merupakan kewajiban setiap muslim dengan mengeluarkan atau menyisihkan sebagian harta yang dimiliki dengan syarat-syarat tertentu dan diberikan kepada setiap muslim dengan syarat-syarat tertentu pula.

Zakat merupakan salah satu rukun Islam, zakat diwajibkan di Madinah pada bulan Syawal tahun kedua Hijriyah, perwajibannya terjadi setelah perwajiban puasa Ramadhan. Dalam Al-Qur'an zakat digandengkan dengan kata shalat sebanyak delapan puluh dua tempat. Hal ini menunjukan bahwa keduanya memiliki keterkaitan yang sangat erat. (Al-Zuhayly, 2005: 98). Selain itu zakat juga menjadi salah satu diantara panji-panji Islam yang tidak boleh diabaikan oleh siapapun juga. Oleh sebab itu, orang yang enggan membayar zakat boleh diperangi dan orang yang menolak kewajiban zakat dianggap kafir. (Mohammad, 2003: 177). Karena dalam penunaian zakat itu memiliki arti yang sangat penting. Adapun hukumnya zakat adalah fardhu 'aindalam arti kewajiban yang ditetapkan untuk diri pribadi dan tidak mungkin dibebankan pada orang lain. (Amir, 2003: 38). Adapun dasar-dasar hukum zakatnya diantaranya adalah:

a. Al-Qur'an

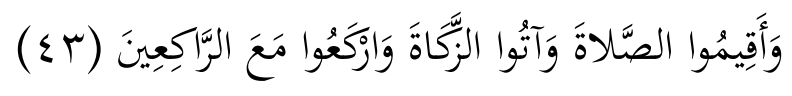

Dan dirikanlah shalat, tunaikanlah zakat dan ruku'lah beserta orang-orang yang ruku'. (Al-Baqarah: 43)

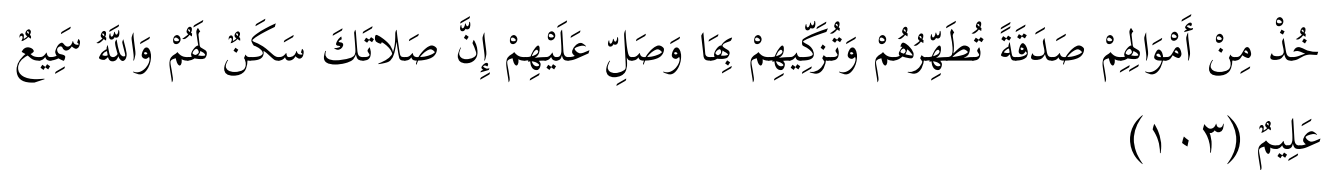

Ambillah zakat dari sebagian harta mereka, dengan zakat itu kamu membersihkan dan mensucikan mereka dan mendoalah untuk mereka. Sesungguhnya doa kamu itu (menjadi) ketenteraman jiwa bagi mereka. dan Allah Maha mendengar lagi Maha mengetahui. (at-Taubah: 103)

b. Hadits

Adapun perintah menunaikan zakat dalam Hadits sebagai berikut:

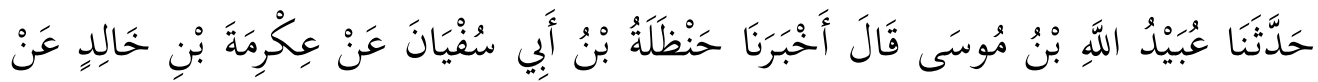




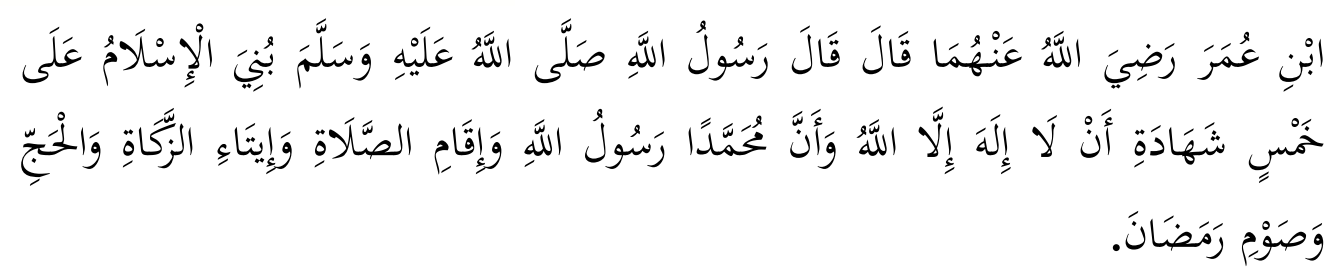

Telah menceritakan kepada kami Abdullah bin Musa dia berkata, telah mengabarkan kepada kami Hanzhalah bin Abu Sufyan dari 'Ikrimah bin Khalid dari Ibnu Umar berkata: Rasulullah shallallahu 'alaihi wasallam bersabda: "Islam dibangun diatas lima (landasan); persaksian tidak ada ilah selain Allah dan sesungguhnya Muhammad utusan Allah, mendirikan shalat, menunaikan zakat, haji dan puasa Ramadlan". (Muttafaq 'alaihi; al-Bukhari, no.8; Muslim, no. 16)

Berdasarkan ayat-ayat dan hadits-hadits di atas, jelas bahwa mengeluarkan zakat itu hukumnya wajib sebagai salah satu rukun Islam. Bahkan dalam sejarah Islam, sahabat Abu Bakar pernah memerangi orang yang tidak menunaikan zakat. Beliau mengatakan dengan tegas bahwa "demi Allah akan kuperangi orang-orang yang membedakan antara shalat dengan zakat". (Ali, 2006: 17). Zakat juga mengandung hikmah. Di antara hikmah disyariatkannya zakat adalah sebagai berikut (Jabir, 2012: 633) yakni : pertama, menyucikan jiwa manusia dari penyakit-penyakit kikir dan pelit, tamak dan rakus. Kedua, membantu orang-orang miskin dan memenuhi kebutuhan orang-orangyang mengalami kekurangan, kesialan dan yang terampas haknya. Ketiga, menegakkan kemaslahatan-kemaslahatan umum, yang menjadi pondasi kehidupan umat dan kebahagiaannya. Keempat, membatasi penumpukan kekayaan hanya pada tangan orang-orang kaya, para pedagang dan pengusaha semata, supaya harta tersebut tidak tertahan di lingkungan kelompok yang terbatas atau hanya beredar di kalangan orang-orang kaya saja.

Secara umum, zakat terbagi atas 2 (dua) yakni zakat fitrah dan zakat maal (baznas.go.id) yakni: pertama, zakat fitrah adalah zakat yang wajib ditunaikan bagi seorang muslim/ah yang sudah mampu untuk menunaikannya. Zakat fitrah harus dikeluarkan setahun sekali pada saat awal bulan Ramadhan hingga batas sebelum sholat hari raya Idul Fitri. Hal tersebut yang menjadi pembeda zakat fitrah dengan zakat lainnya. Sebagaimana tercantum pada hadits Rasulullah SAW mengatakan, "Barangsiapa yang menunaikan zakat fitri sebelum shalat Id maka 
zakatnya diterima dan barangsiapa yang menunaikannya setelah shalat Id maka itu hanya dianggap sebagai sedekah di antara berbagai sedekah." (HR. Abu Daud). Kedua, zakat maal, menurut bahasa harta adalah segala sesuatu yang diinginkan sekali oleh manusia untuk memiliki, memanfaatkan dan menyimpannya. Sedangkan menurut istilah, harta adalah segala sesuatu yang dapat dimiliki (dikuasai) dan dapat digunakan (dimanfaatkan). Sesuatu dapat disebut dengan maal (harta) apabila memenuhi 2 (dua) syarat, yaitu: Dapat dimiliki, disimpan, dihimpun, dikuasai dan dapat diambil manfaatnya sesuai dengan ghalibnya. Syarat harta yang wajib di zakati yaitu, milik penuh, bertambah atau berkembang, cukup nisab, lebih dari kebutuhan pokok, bebas dari hutang, dan sudah berlalu satu tahun (haul). Nisab zakat maal: adalah 85 gram emas dan Kadar zakat maal: 2,5\%.

2. Konsep manajemen

Manajemen dalam kata serapan dari bahasa Inggris "management" yang berakar kata "manage" yang berarti "control" dan "succed" sukses. Dari sini dapat disimpulkan inti dari manajemen adalah pengendalian hingga mencapai sukses yang diinginkan. Adapun manajemen secara terminologi diartikan sebagai proses perencanaan, pengorganisasian, pengarahan dan pengawasan usaha para anggota organisasi dengan menggunakan sumber daya yang ada agar mencapai tujuan yang sudah ditetapkan. (Eri, 2004: 63). Adapun pendapat para ahli mengenai definisi manajemen di anataranya sebagai berikut:

a. Menurut Didin Hafidhuddin dan Hendri Tanjung. Proses-proses manajemen pada dasarnya adalah perencanaan segala sesuatu secara mantap untuk melahirkan keyakinan yang berdampak pada melakukan sesuatu sesuai dengan aturan serta memiliki manfaat. Perbuatan yang tidak ada manfaatnya adalah sama dengan perbuatan yang tidak pernah direncanakan. Jika perbuatan itu tidak pernah direncanakan, maka tidak termasuk dalam kategori manajemen yang baik. (Didin dan Hendri, 2003: 3).

b. Menurut Menurut Muhammad Abdul Jawwad Manajemen adalah Aktivitas menertibkan, mengatur, dan berpikir yang dilakukan oleh seseorang, sehingga dia mampu mengurutkan, menata, danmerapikan hal-hal yang ada di sekitarnya, mengetahui prioritas-prioritasnya, serta menjadikan hidupnya selalu selaras dan serasi dengan yang lainnya. 
(Abdul, 2004: 119).

Dari beberapa uraian di atas, dapat disimpulkan bahwa manajemen adalah pengelolaan suatu pekerjaan yang terdiri dari planning (perencanaan), organizing (organisasi), actuating (kepemimpinan) dan controlling (pengawasan), untuk memperoleh hasil dalam rangkapencapaian tujuan yang telah ditentukan. Pengelolaan pekerjaan itu terdiri dari berbagaimacam ragam, misalnya berupa pengelolaan industri, pemerintahan, pendidikan, pelayanansosial, olah raga dan lain sebagainya. Dengan kata lain, berbagai jenis kegiatan yang berbedaitulah yang membentuk manajemen sebagai suatu proses yang tidak bisa dipisahkan dansangat erat hubungannya. Bahkan hampir setiap aspek kehidupan manusia memerlukanpengelolaan. Oleh karena itu, manajemen ada dalam setiap aspek kehidupan manusia, dimanaterbentuk suatu kerjasama (organisasi).

3. Manajeman Zakat BAZNAS Kota Makassar

Pengelolaan manajemen zakat yang dilakukan oleh Badan Amil Zakat Nasional Kota Makassar, di mulai dari tingkatan kelurahan, kecamatan dengan yang ditangani oleh bidang Kesejahteraan Masyarakat baik di kelurahan maupun di Kecamatan. Penetapan kepengurusan BAZNAS Kota Makassar ditetapkan berdasarkan surat keputusan Kepala Kantor Wilayah Kementrian Agama Provinsi Sulawesi Selatan. Sebagaimana dijelaskan di atas dapat dipahami bahwa pengelolaan zakat itu diawali dengan kegiatan perencanaan yang meliputi perencanaan suatu program beserta budgetingnya serta pengumpulan data muzakki dan mustahiq, kemudian pengorganisasian meliputi struktur organisasi (Dewan Pertimbangan, Komisi Pengawas dan Badan Pelaksana), penempatan orang-orang (amil) yang tepat dan pemilihan sistem pelayanan yang memudahkan ditunjang dengan perangkat lunak (software) yang memadai, kemudian dengan tindakan nyata (pro aktif) melakukan sosialisasi serta pembinaan baik kepada muzakki maupun mustahiq dan terakhir adalah pengawasan dari sisi syariah, manajemen dan keuangan operasional pengelolaan zakat. Empat hal diatas menjadi persyaratan mutlak yang harus dilakukan terutama oleh organisasi pengelola zakat baik oleh BAZNAS maupun LAZ yang profesional. Adapun Manajeman zakat yang dilakukan oleh BAZNAS Kota Makassar meliputi : 
a. Perencanaan BAZNAS Kota Makassar. Sebuah perencanaan biasanya terkait dengan beberapa hal, antara lain terkait denganwaktu. Perencanaan dengan waktu biasanya dibagi dalam tiga babak, yakni perencanaan jangka pendek, jangka menengah dan jangka panjang. Yang dimaksud perencanaan jangka pendek adalah perencanaan yang dibatasi waktunya dalam kisaran satu tahun, sedangkan perencanaan jangka menengah adalah biasanya dilakukan dalam kisaran satu sampai tiga tahun, untuk jangka panjangnya biasanya dibutuhkan waktu lima tahunan. Kisaran waktu tersebut bisa dirubah-rubah sesuai dengan kebutuhan masing-masing organisasi, yang penting dalam perencanaan adalah adanya kegiatan yang jelas dan adanya kesinambungan yang akandilakukan oleh sebuah oraganisasi dengan setandar pencapaian yang telah dirancangkan. Dari paparan tersebut jelas bahwa BAZNAS Kota Makassar juga merumuskan langkah-langkah sebuah perencanaan, baik perencanaan program jangka pendek, jangka menengah maupun perencanaan Jangka Panjang. Sebagaimana hasil wawancara kami dengan Wakil Ketua II Arifuddin Ahmad beliau mengatakan:

Kalau program jangka pendek seperti bantuan langsung tunai, pemberian bantuan bencana tetapi juga berefek panjang karena kapanpun terjadi maka di berikan bantuan akan tetapi dari segi pengunaannya pendek begitupun jangka menengah seperti pelatihan jahit, LAS, perbaikan AC dan perindustrian serta dengan memberikan bantuan modal akan tetapi dalam jangka panjang juga karena tetap kami mengevaluasi keberadaan mereka.

Arifuddin Ahmad juga menambahkan :

Bentuk evaluasi kami adalah dengan terjun langsung kelapangan mengadakan survei kepada para mustahik yang di berikan pelatihan untuk melihat kendala atau masalah yang dihadapi. Adapun ketika terdapat masalah maka kami akan memberikan pelatihan lain yang cocok untuk para mustahik. Tapi untuk saat ini Alhamdulillah belum ada masalah yang kami temui, cuman yang menjadi hambatan mungkin adalah tindak lanjut dari program akan tetapi ketika yang sudah berhasil atau meningkat usahanya akan di berikan bantuan 
seperti yang jahit yang sudah meningkat menjadi sulam. Untuk sumber pendanaan dari perencanaan bersumber dari dana zakat profesi dan infak haji serta dari masyarakat yang menyetor kesini. Walaupun belum terlalu efektif hal ini dikarenakan banyaknya LAZ dan belum turunya juklak UU No. 23 Tahun 2011ini sudah hampir dua tahun artinya pemerintah kita belum ada keseriusan padahal sumber pendapatan negara yang baik adalah dengan zakat, maunya juga kami untuk zakat ini lewat satu pintu dipegang oleh negara saja.

Dari hasil wawancara di atas dapat dipahami bahwa program-program perencanaan yang dilaksanakan oleh BAZNAS Kota Makassar masih berjalan dengan lancar dan sesuai dengan tujuan, walaupun ada beberapa kendala-kendala yang dihadapinya sebagaimana yang telah disebutkan di atas. Hal ini di karenakan para pengurus BAZNAS Kota Makassar dalam melaksanakan tugasnya selain di pantau oleh pengawas, dia juga bekerja dengan sungguh-sungguh, jujur dan selalu transparan.

b. Pengorganisasian BAZNAS Kota Makassar. Secara sederhana bisa juga dikatakan bahwa pengorganisasian itu mengatur pekerjaan apa yang perlu ada, berapa banyak dan seperti apa orang yang harus mengerjakan pekerjaan itu. Semua itu dilengkapi dengan seperti apa tanggung jawabnya dan bagaimana hubungan antar fungsi. Hubungan ini ditata dalam sebuah struktur organisasi. Untuk mengetahui sturktur organisasi BAZNAS Kota Makassar, maka peneliti mencari data dokumentasi yang ada di BAZNAS Kota Makassar, bahwa struktur organisasi BAZNAS Kota Makassar yakni meliputi sebagai berikut :

Gambar 1 : Struktur Organisasi Badan Amil Zakat Nasional Kota Makassar 


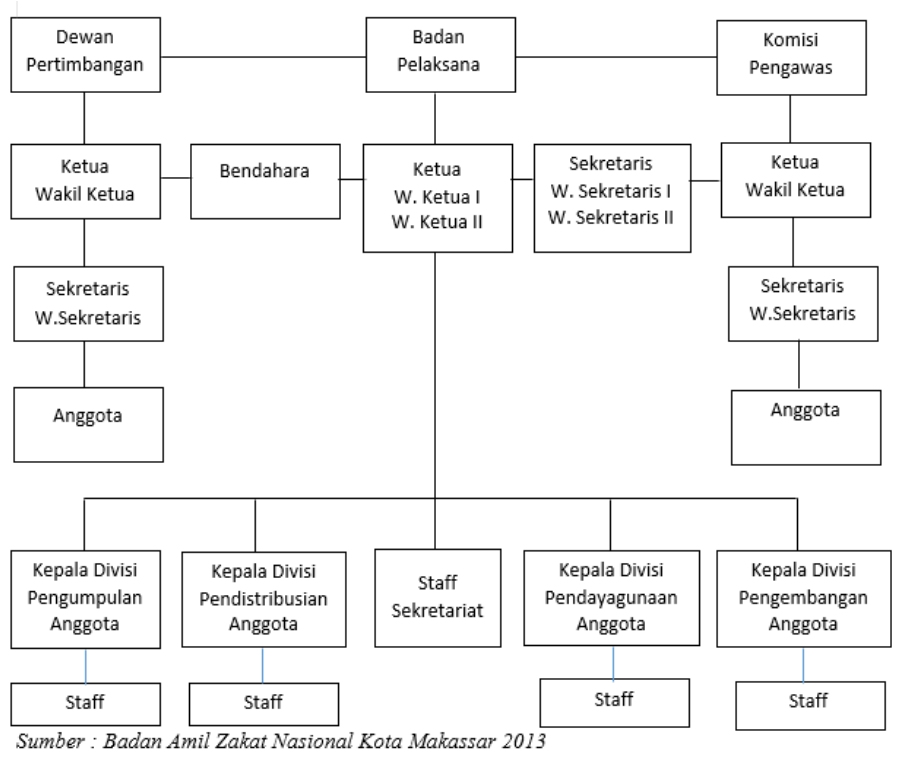

Dari gambar 1 dapat dipahami bahwa struktur itu mempunyai makna atau maksud tertentu. Yang mana dalam struktur tersebut sudah tergambarkan tugas masing-masing individu kepengurusan. Begitu pula struktur BAZNAS Kota Makassar sebagaimana peneliti dijelaskan oleh Wakil Ketua II Arifuddin Ahmad, beliau menjelaskan bahwa :

Untuk jalur koordinasinya yah mengikuti UU, adapun badan pengawas setiap semester datang untuk mengaudit, untuk koordinasi dengan badan pelaksana dengan musuyawarah dan raker tahunan serta dalam setiap musyawarah kami mengundang dewan pertimbangan untuk memberikan saran, masukan, dan usul.

Dengan demikian dari hasil wawancara di atas dapat diketahui bahwa setiap struktur organisasi itu sudah tergambarkan aktifitas kerja para personil kepengurusan dan menunjukkan bagaimana fungsi atau aktivitas yang beraneka macam dihubungkan sampai batas tertentu. Sebagaimana struktur di BAZNAS Kota Makassar, mulai Dewan Pertimbangan yang berperan sebagai pemberi timbangan kemudian di serahkan kepada Badan Pelaksana yang bertanggung jawab atas pelaksanaan program tersebut. Dari pantauan peneliti dilapangan pengorganisasian yang dilakukan Badan Amil Zakat Nasional Kota Makassar, bisa di katakan sudah mulai terkonsep dan terorganisir, pernyataan tersebut berdasarkan dengan adanya 
struktur kepengurusan di Badan Amil Zakat Nasional Kota Makassar. Namun hal tersebut belum bisa dinyatakan pengorganisasian yang sempurna karena sampai saat ini dalam struktur organisasi Badan Amil Zakat Nasional Kota Makassar terdapat dualisme amanah sehingga menyulitkan pengkoordinasian.

4. Pelaksanaan Pengelolaan Dana ZIS di Kantor BAZNAS Kota Makassar

Kegiatan ketiga dari sebuah manajeman adalah pelaksanaan yang dilakukan setelah sebuah organisasi memiliki perencanaan dan melakukan pengorganisasian dengan memiliki struktur organisasi, termasuk tersedianya personil sebagai pelaksana sesuai dengan kebutuhan kerja yang dibentuk. Pelaksanaan dalam sebuah manajeman adalah aktualisasi perencanaan yang dicanangkan oleh organisasi. Ada dua dalam melakukan pelaksanaan pengelolaan zakat, yaitu Pelaksanaan Dalam Penghimpunan Zakat dan Pelaksanaan Dalam Pendistribusian Zakat.

a. Pelaksanaan Penghimpunan.

Penghimpunan dana zakat adalah kegiatan mengumpulkan dana zakat dari para muzakki kepada organisasi pengelola zakat untuk disalurkan kepada yang berhak menerima (mustahik) sesuia dengan ukurannya masing-masing. Pengumpulan dana zakat dan infak dan shadaqah yang dilakukan Badan Amil Zakat Nasional Kota Makassar adalah dengan cara menerima atau mengambil langsung dari muzakki atas dasar pemberitahuan muzakki. Badan Amil Zakat Nasional Juga bekerjasama dengan Bank dalam pengumpulan zakat, infak, dan shadaqah. Sebagaimana yang dikatakan Wakil Ketua II Arifuddin Ahmad :

Dalam penghimpunan dana zakat, infak, dan shadakah di BAZNAS Kota Makassar, yang pertama bisa melalui transfer langsung ke rekening yang dimiliki BAZNAS Kota Makassar, kedua menyerahkan langsung kepada Amil atau pengurus BAZNAS yang ada di Kantor BAZNAS ini, ketiga melalui UPZ-UPZ yang dibentuk berdasarkan SKPD kantor-kantor pemerintahan kota makassar

Selain informan Arifuddin Ahmad, peneliti juga mendapatkan keterangan mengenai penghimpunan dana zakat yang ada di Badan Amil Zakat Nasional Kota Makassar dari Miswar yang juga selaku 
amil zakat di BAZNAS Kota Makassar menyatakan :

Untuk pengumpulan zakat disini biasanya kami merima langsung di BAZNAS dan kalau ada telfon dari para muzakki yang ingin berzakat atau berinfak maka kami akan jemput.

Dari hasil wawancara di atas jelas para muzakki sekarang bisa dengan mudah dalam menyalurkan zakatnya karena terdapat layanan yang baik oleh para amil BAZNAS. Hal ini bisa dilihat dari adanya layanan jemput langsung kerumah para muzakki, artinya juka muzakki tersebut ingin menyalurkan zakat, infak dan shadakah, akan tetapi dia sibuk dengan kegiatannya maka dia tidak perlu datang ke kantor BAZNAS Kota Makassar. Melainkan cukup menghubungi layanan jemput zakat. Selain itu layanan lainnya adalah para muzakki dapat langsung mentransfer ke rekening yang dimiliki oleh BAZNAS Kota Makassar.

Untuk pengumpulan dana zakat dan infak di BAZNAS Kota Makassar mengalami peningkatan setiap tahun walaupun di tahun 2011 dan 2012 mengalami penurunan sedangkan untuk infak PNS dan Haji Mengalami kenaikan setiap tahunnya. Berikut ini laporan kas dana zakat dan infak di BAZNAS Kota Makassar empat tahun terakhir.

Tabel 1 : Penerimaan Dana Zakat BAZNAS Kota Makassar tahun 2009-2012

\begin{tabular}{|c|c|c|c|}
\hline No. & Tahun & Penerimaan Zakat & Persentase Fluktuasi \\
\hline 1. & 2009 & Rp. 238.217.419,- & \\
\hline 2. & 2010 & Rp. 264.668.409,- & $11 \%$ \\
\hline 3. & 2011 & Rp. $130.720 .900,-$ & $50 \%$ \\
\hline 4. & 2012 & Rp. 111.740.400,- & $14 \%$ \\
\hline \multicolumn{2}{|c|}{ Jumlah } & Rp. 745.347.128,- & $25 \%$ \\
\hline
\end{tabular}

Sumber : Badam Amil Zakat Nasional Kota Makassar 2013

Dari tabel diatas, dapat diketahui bahwa penerimaan zakat yang dilakukan BAZNAS Kota Makassar selama empat tahun terakhir yaitu dari tahun 2009 sampai tahun 2012 telah mengalami fluktuasi. Pada tahun 2009 dana zakat yang berhasil dikumpul sekitar Rp. 238.217.419,- kemudian pada tahun 2010 mengalami peningkatan sekitar 11 \% atau naik sekitar Rp. 26.450.990,-. Pada tahun 2011 mengalami penurunan sebesar $50 \%$ atau turun sekitar Rp. 
133.947.509,-. Begitu pun pada tahun 2012 mengalami penurunan $14 \%$ atau turun sekitar 18.980.500,-. Secara Keseluruhan dana zakat yang berhasil dihimpun dana BAZNAS Kota Makassar selama empat tahun terakhir sebesar Rp. 745.347.128,-. Sedangkan data penerimaan dana infak PNS sebagai berikut :

Tabel 2 : Penerimaan Dana Infak PNS BAZNAS Kota Makassar tahun 2009-2012

\begin{tabular}{cccc}
\hline No. & Tahun & Penerimaan & Persentase Peningkatan \\
\hline 1. & 2009 & Rp. 1.592.115.157,- & \\
2. & 2010 & Rp. 2.551.669.525,- & $60 \%$ \\
3. & 2011 & Rp. 3.643.151.025,- & $42 \%$ \\
4. & 2012 & Rp. 4.740.658.625,- & $30 \%$ \\
\hline & Jumlah & Rp. 12.527.594.332,- & $44 \%$ \\
\hline
\end{tabular}

Sumber : Badam Amil Zakat Nasional Kota Makassar 2013

Untuk penerimaan infak PNS di BAZNAS Kota Makassar, dengan melihat tabel diatas dari tahun ke tahun mengalami peningkatan. Pada tahun 2009 dana infak PNS yang berhasil dikumpul sekitar Rp. 1.592.111.157,-. Kemudian tahun 2010 mengalami peningkatan sebesar $60 \%$ atau naik sekitar Rp. 959.554.368,-. Pada tahun 2011 mengalami peningkatan sebesar $42 \%$ atau naik sebesar Rp. 1.091.481.500,-. Begitu pun pada tahun 2012 mengalami peningkatan sebesar 30\% atau naik sebesar Rp. 1.097.507.600,-. Secara keseluruhan dana infak PNS yang berhasil dihimpun BAZNAS Kota Makassar selam 4 tahun terakhir sekitar Rp. 12.527.594.332,-. Adapun data penerimaan dana infaq Haji sebagai berikut :

Tabel 3 : Penerimaan Dana Infaq Haji BAZNAS Kota Makassar tahun 2009-2012

\begin{tabular}{ccccc}
\hline No. & Tahun & \multicolumn{2}{c}{ Penerimaan } & Persentase Peningkatan \\
\hline 1. & 2009 & Rp. & $257.788 .000,-$ & \\
2. & 2010 & Rp. & $636.438 .000,-$ & $146 \%$ \\
3. & 2011 & Rp. & $989.938 .000,-$ & $55 \%$ \\
4. & 2012 & Rp. $1.375 .278 .000,-$ & $38 \%$ \\
\multicolumn{2}{r}{ Jumlah } & Rp. 3.259.442.000,- & $79,66 \%$ \\
\hline
\end{tabular}

Sumber : Badam Amil Zakat Nasional Kota Makassar 2013

Sedangkan penerimaan infaq haji di BAZNAS Kota Makassar juga mengalami peningkatan dari tahun ke tahun. Pada tahun 2009 dana infaq haji yang berhasil di kumpulkan sebesar Rp. 257.788.000,-. Kemudian di tahun 2010 mengalami peningkatan sebesar $146 \%$ atau naik sekitar Rp. 378.650.000,-. Pada tahun 2011 juga mengalami 
peningkatan sebesar 55\% atau naik sekitar Rp. 353.500.000,-. Begitu pun pada tahun 2011 yang juga mengalami peningkatan sebesar $38 \%$ atau naik sebesar Rp. 385.340.000,-. Secara keseluruhan dana infaq haji yang berhasil dihimpun BAZNAS Kota Makassar selama 4 tahun terakhir sekitar Rp. 3.259.442.000,-

b. Pendistribusian Dana ZIS di BAZNAS Kota Makassar

Pendistribusian zakat yang dilakukan BAZNAS Kota Makassar ada dua macam, yaitu : pertama, pendistribusian secara konsumtif maksudnya penyaluran dana yang langsung dibutuhkan oleh mustahiq. Kedua, pendistribusian secara produktif maksudnya pemberian dana zakat berupa bantuan-bantuan produktif untuk meningkatkan taraf hidup mereka. Berdasarkan hasil wawancara oleh H. Katjong selaku bendahara di BAZNAS Kota Makassar menjelaskan bahwa :

Pelaksanaan pendistribusian di BAZNAS Kota Makassar ini memiliki dua program, yaitu: pertama, bersifat konsumtif dalam artian pendistribusian yang diberikan secara tunai atau langsung habis. Kedua, bersifat produktif dalam artian pendistribusian yang diberikan berupa pelatihan-pelatihan kepada para mustahik.

Pendistribusian dan zakat ini sesuai delapan ashnaf (golongan) yang berdasarkan QS. At-Taubah ayat 60 yang terdiri atas: Fakir, Miskin, Amil, Muallaf, riqab, atau memerdekakan budak sudah tidak ada lagi sehingga pendistribusian hanya menjadi tujuh golongan. Adapun bentuk penyaluran kepada mustahik adalah melalui program kerja yang telah dimusyawarahkan dan juga terkadang ada yang langsung ke kantor BAZNAS Kota Makassar langsung diberikan bantuan tunai. Untuk penyaluran warga pra sejahtera BAZNAS Kota Makassar memberikan surat kepada Kecamatan untuk kemudian pihak Kecamatan memberikan amanah kepada pihak kelurahan untuk mendata warganya yang berhak menerima (mustahiq). Sebagaimana hasil wawancara peneliti dengan salah seorang staff kesejahteran sosial di Kecamatan Panakkukang, beliau mengatakan:

Untuk Pembagian zakat kami hanya diberikan surat dari BAZNAS Kota Makassar yang selanjutnya kami serahkan 
kepada Kelurahan. Walaupun dalam hal ini pendistribusian masih bersifat kekeluargaan bahkan terkadang pembagian BLT biasanya ada yang pakai Kalung, Gelang, dan Cincin yang dapat BLT. Namun untuk pembagiannya di Kecamatan dan BAZNAS Kota Makassar yang langsung memberikan bantuannya.

Dari hasil wawancara diatas dapat disimpulkan bahwa pendistribusian untuk warga pra sejarah masih belum berjalan dengan maksimal. Bahkan peneliti sempat mewancarai salah seorang warga di kelurahan paropo kecamatan panakkukang ibu halimah yang bekerja sebagai buruh harian beliau mengatakan :

Tidak ada kami dapat, yang kami dapat hanya beras belum ada dalam bentuk uang. Pendapatan suami kami hanya Rp. 500.000,sampai Rp. 1.000.000,- per bulan, terkandung hasil jualan barang bekas yang kami kumpulkan, saya sendiri Cuma ibu rumah tangga. Saran kami supaya kami ini kodong didata, bisa juga di perbaiki rumahku, bedah rumah. Supaya anak-anak kami juga bisa sekolah

Dari hasil wawancara yang kami dapatkan diatas, ini langsung kami laporkan ke BAZNAS Kota Makassar ini. Serta langsung mewawancarai amil zakat $\mathrm{H}$. Katjong, beliau mengatakan :

Untuk hal seperti itu kami serahkan tanggung jawabnya kepada kelurahan kami juga tidak bisa memberikan sanksi tegas karena di UU belum ada sangksi tegas yang menjelaskan seperti kejadian tersebut. Biasanya kami hanya memberikan surat teguran"

Menurut peneliti sebenarnya program yang dicanangkan oleh BAZNAS Kota Makassar sudah baik akan tetapi tidak adanya sanksi yang tegas sehingga pembagian atau pendistribusian kasus diatas masih sering terjadi.

\section{Pengawasan di Kantor BAZNAS Kota Makassar}

Tidak sedikit pakar yang menekankan bahwa perencanaan dan pengawasan merupakan dua sisi mata uang yang sama. Artinya pengawasan memang di maksudkan untuk lebih menjamin bahwa semua kegiatan yang diselenggarakan dalam suatu organisasi didasarkan pada suatu rencana, termasuk suatu strategi yang telah ditetapkan sebelumnya. 
Pengawasan diperlukan untuk mencegahnya terjadinya deviasi dalam operasionalisasi suatu rencana, sehingga berbagai kegiatan operasional yang sedang berlangsung terlaksana dengan baik. dalam artian bukan hanya sesuai dengan rencana, melainkan juga dengan tingkat efisien dan effektifitas yang setinggi mungkin.

Karena tidak perencanaan yang baik, bila tidak ada pengawasan yang baik. sebaliknya tidak yang bisa diawasi bila tidak merencanakan apa-apa. Pengawasan merupakan fungsi yang terakhir dalam kegiatan manajemen yang pada dasarnya berfungsi untuk memastikan bahwa tujuan yang telah ditetapkan organisasi dapat tercapai sesuai dengan rencana. Berdasarkan dari hasil wawancara dengan Wakil Ketua II Arifuddin Ahmad, beliau mengatakan :

Untuk pengawasanya yang ada di BAZNAS Kota Makassar, bentuknya terbagi dua yaitu internal dan eksternal, bentuk pengawasan internal degan mengirimkan laporan pertangggung jawab ke DPRD dan Walikota Makassar.Dan bentuk pengawasan dari eksternal adalah audit yang dilakukan oleh orang luar, misalnya tahun kemarin yang datang untuk pengawas eksternal dari Universitas Hasanuddin.

Dengan demikian, bentuk pengawasan yang ada di BAZNAS Kota Makassar ada dua yaitu; pertama, dengan pengawasan internal yaitu dengan memberikan laporan pertanggung jawaban kepada DPRD dan Walikota Makassar untuk mengetahui sejauh mana perkembangan lembaga, kinerja pelaksanaannya, dan kendala atau hambatan yang dihadapinya. Hal ini sangat perlu dilakukan dalam rangka perbaikan dan penyempurnaan menuju tingkat perkembangan yang diinginkan. Kedua, bentuk pengawasannya melalui eksternal yaitu mendatangkan pihak lain untuk mengaudit lembaga. Untuk BAZNAS Kota Makassar pada tahun 2012 mendatangkan pihak Universitas Hasanuddin yang langsung datang ke kantor BAZNAS dan langsung mengadakan pengauditan lembaga. Pengendalian yang dilakukan seperti ini merupakan hal yang sangat baik, dimana kecurangan dalam hal laporan pertanggung jawaban dapat diminimalisir.

Dalam melakukan pengawasan terhadap organisasi tidak hanya sekedar mengawasi begitu saja, melainkan ada tujuan tertentu dalam 
pengawasan tersebut. Sebagaimana yang disampaikan oleh H. Katjong, beliau mengatakan :

Dalam melakukan pengawasan sebuah organisasi itu ada tujuannya, yaitu : pertama, kita dapat menjalankan amanah sesuai dengan syariat Islam dan yang kedua, agar para amil zakat di BAZNAS Kota Makassar dapat bekerja tidak dengan seenaknya saja. Dalam rapat pleno kami juga mengundang badan pengawas untuk memberikan saran dan usulannya

Dari hasil wawancara di atas dapat dipahami bahwa pentingnya pengawasan dalam sebuah organisasi, karena adanya pengawasan maka bisa mengetahui kendala-kendala atau hambatan apa saja yang dihadapi oleh sebuah organisasi dalam melaksanakan program kerjanya. Dengan di ketahuinya kendala-kendala tersebut, maka dalam melaksanakan program kerjanya dikemudian hari, bisa sesuai dengan harapan. Minimal bisa menimalisir kendala-kendala yang dihadapinya tersebut. Selain itu, pengawasan juga dapat mencegah perbuatan yang menyalahi aturan yang dilakukan oleh anggota organisasi.

\section{SIMPULAN}

Berdasarkan hasil penelitian yang dilakukan oleh penulis tentang manajemen zakat di Badan Amil Zakat Nasional Kota Makassar, maka penulis menyimpulkan bahwa perencanaan yang dilakukan Badan Amil Zakat Nasional Kota Makassar terbagi atas tiga babak yaitu program jangka pendek, jangka menengah, jangka panjang. Pengorganisasian yang dilakukan Badan Amil Zakat Nasional Kota Makassar terbagi atas tiga yaitu Dewan Pertimbangan, Badan Pelaksana yang terdiri dari ketua, wakil ketua, bendahara, divisi pengumpulan, divisi pendistribusian, divisi pendayagunaan, divisi pengembangan, staff dan Komisi Pengawas.

Pelaksanaan yang dilakukan Badan Amil Zakat Nasional Kota Makassar terbagi atas dua, yaitu Pertama, pengumpulan dana zakat yang dilakukan oleh BAZNAS Kota Makassar dilakukan dengan tiga cara; layanan jemput zakat, muzakki mengantar langsung ke BAZNAS Kota Makassar, dan melalui transfer kerekening BAZNAS. Kedua, pendistribusian zakat yang dilakukan BAZNAS Kota Makassar ada dua macam; pendistribusian secara konsumtif maksudnya penyaluran dana zakat yang langsung dibutuhkan mustahik. Kedua, pendistribusian secara 
produktif maksudnya pemberian dana zakat berupa bantuan-bantuan produktif untuk meningkatkan taraf hidup mereka.

Pengawasan yang dilakukan oleh Badan Amil Zakat Nasional Kota Makassar terbagi atas dua yaitu secara internal yang dilakukan oleh komisi pengawas BAZNAS Kota Makassar dan dari eksternal yang dilakukan oleh lembaga luar, pada tahun 2012 lembaga yang mengadakan audit di BAZNAS Kota Makassar adalah dari Pihak Universitas Hasanuddin. Dari hasil terakhir pemeriksaan yang dilakukan Pihak Universitas Hasanuddin, manajemen BAZNAS Kota Makassar dinyatakan bebas dari temuan negatif atau tidak ada indikasi penyelewengan dana ZIS.

\section{DAFTAR RUJUKAN}

Al-Jaza 'iri, Abu Bakar Jabir. (2012). Minhajul Muslim: Konsep Hidup Ideal Dalam Islam. (Penerjemah; Mustofa Aini, et.all) Jakarta: Darul Haq

Al-Zuhayly, Wahbah. (2005). Zakat Kajian Berbagai Mazhab. Bandung: Remaja Rosdakarya

Ar-Rahman, Mohammad Abdul Malik. (2003). Zakat 1001 Masalah dan Solusinya, Jakarta: Pustaka Cerdas

Beik, Irfan Syauqi, et.all. (2011). Indonesia Zakat dan Development Report 2011, Kajian Empiris Peran Zakat dalam Pengentasan Kemiskinan. Ciputat: Indonesia Magnifinence of Zakat

Hafidhuddin, Didin. (1998). Panduan Praktis Tentang Zakat, Infak, dan Sedekah. Jakarta: Gema Insani

Hafidhuddin, Didin. (2002). Zakat dalam Perekonomian Modern, Jakarta: Gema Insani

Hafidhuddin, Didin dan Hendri Tanjung. (2003). Manajemen Syariah Dalam Praktiknya. Jakarta: Gema Insani Press

Hasan, M. Ali. (2006). Zakat dan Infak: Salah Satu Solusi Mengatasi problema Sosial di Indonesia. Jakarta: Prenada Media Group

Inoed, Amiruddin, et. All. (2000). Anatomi Fiqh Zakat Potret dan Pemahaman Badan Amil Zakat Sumatra Selatan. Yogyakarta: Pustaka Pelajar Jawwad, Muhammad Abdul. (2004). Menjadi Manajer Sukses. Jakarta: Gema Insani 
Muhammad. (2007). Aspek Hukum Dalam Muamalah, Yogyakarta: Graha Ilmu

Moleong, Lexy J. (2007). Metodologi Penelitian Kualitatif. Bandung: Rosda

Nawawi, Hadari dan Himi Martini. (1996). Penelitian Terapan. Yogyakarta: Gajah Mada University Press

Qardawi, Yusuf. (1999). Hukum Zakat. Bogor: Litera Antar Nusa

Sudewo, Eri. (2004). Manajemen Zakat. Jakarta: Institut Manajemen Zakat

Syarifuddin, Amir, (2003). Garis-Garis Besar Fiqih. Bogor: Kencana

http://www.voa-islam.com, di akses pada 20 April 2013

http://www.tempo.com di akses pada 20 April 2013

http://www.baznas.go.id diakses pada 03 Oktober 2019 